\title{
Effect of $\beta$-caryophyllene from Cloves Extract on Helicobacter pylori Eradication in Mouse Model
}

\author{
Da Hyun Jung ${ }^{1}$, Mi Hee Park ${ }^{2}$, Chul Jin Kim ${ }^{2}$, Jin Young Lee ${ }^{2}$, Chang Yeop Keum ${ }^{2}$, \\ In Seon Kim ${ }^{2}$, Chang-Hyun Yun ${ }^{3}$, Sung-kyu Kim ${ }^{2}$, Won Ho Kim ${ }^{1}$ and Yong Chan Lee ${ }^{1, *}$ \\ 1 Department of Internal Medicine, Yonsei University College of Medicine, Seoul 03722, Korea; \\ jungdh@yuhs.ac (D.H.J.); kimwonho@yuhs.ac (W.H.K.) \\ 2 SFC bio Co., Ltd., 119, Dandae-ro, Dongnam-gu, Cheonan-si, Chungnam 31116, Korea; \\ mhpark@sfcbio.com (M.H.P.); cjkim@sfcbio.com (C.J.K.); jylee@sfcbio.com (J.Y.L.); \\ cykeum@sfcbio.com (C.Y.K.); iskim@sfcbio.com (I.S.K.); skkim@sfcbio.com (S.-k.K.) \\ 3 New Drug \& Bio Research Center, Handok Inc. 2nd floor, A-dong, BioPark, 700, Daewangpangyo-ro, \\ Bundang-gu, Seongnam-si 13488, Korea; ChangHyun.Yun@handok.com \\ * Correspondence: leeyc@yuhs.ac; Tel.: +82-2-2228-1960; Fax: +82-2-362-6884
}

Received: 6 March 2020; Accepted: 2 April 2020; Published: 4 April 2020

\begin{abstract}
New antibacterial treatments against Helicobacter pylori are needed as $H$. pylori is acquiring antibiotic resistance. $\beta$-caryophyllene is a natural bicyclic sesquiterpene, with anti-inflammatory and antimicrobial effects. This study investigates the effects of H-002119-00-001 from $\beta$-caryophyllene on the eradication of $H$. pylori in a mouse model, and its effects on the inflammation of the gastric mucosa. To evaluate the anti-H.pylori efficacy of $\beta$-caryophyllene, a total of 160 mice were divided into eight groups ( $n=10$ each) and were administered different treatments for 2 and 4 weeks. H. pylori eradication was assessed using a Campylobacter-like organism (CLO) test and H. pylori qPCR of the gastric mucosa. The levels of inflammation of gastric mucosa were assessed using histology and immunostaining. H-002119-00-001 decreased bacterial burden in vitro. When H-002119-00-001 was administered to mice once daily for 2 weeks, cure rates shown by the CLO test were $40.0 \%, 60.0 \%$, and $70.0 \%$ in groups 6,7 , and 8 , respectively. H. pylori levels in gastric mucosa decreased dose-dependently after H-002119-00-001 treatment. H-002119-00-001 also reduced levels of inflammation in gastric mucosa. H-002119-00-001 improved inflammation and decreased bacterial burden in $H$. pylori-infected mouse models. H-002119-00-001 is a promising and effective therapeutic agent for the treatment of H. pylori infection.
\end{abstract}

Keywords: $\beta$-caryophyllene; Helicobacter pylori; eradication

\section{Introduction}

Helicobacter pylori is a Gram-negative spiral-shaped bacillus that infects more than half of the global population [1,2]. Generally, H. pylori infection is acquired during childhood, and if left untreated, it can remain with the body of the patient throughout his/her life [3,4]. H. pylori colonization causes a number of human diseases, including chronic gastritis, peptic ulcer, gastric adenocarcinoma, and primary gastric lymphoma [5,6]. Therefore, eradication is important for treating and preventing H. pylori infection-related diseases $[7,8]$. Standard triple therapy (STT), which consists of proton pump inhibitor (PPI), amoxicillin, clarithromycin or metronidazole, was developed in the 1990s and is recommended as the first-line eradication therapy due to a substantial $H$. pylori eradication rate $[9,10]$. However, the rate of $H$. pylori eradication by STT has decreased because of increasing antibiotic resistance. Therefore, there is an increasing demand for safe and effective non-antibiotic compounds that inhibit the growth of H. pylori [11-13]. Recent studies have shown that lower incidence of 
H. pylori infection has been associated with the consumption of many foods of vegetal origin, including green tea and wine, which are rich in phytochemicals such as anthocyanidins, tannins, flavones, isoflavones, flavo- and flavanols, and stilbene derivatives [14-16]. $\beta$-caryophyllene is a natural bicyclic sesquiterpene that is present in a wide range of plant species such as cloves, basil, and cinnamon leaves, and copaiba balsam. [17] It ((1R,4E,9S)-4,11,11-trimethyl-8-methy lidenebicyclo [7.2.0] undec-4-ene) is a major constituent of many essential oils obtained from a number of plant species such as the Syzygium ( 13\%), Betula $(\sim 30 \%)$, and Strobilanthes ( 7\%) species [18-20]. It has been known to have anti-inflammatory, antioxidant, anticancer, and antimicrobial effects [21-24]. In this study, we used the $\beta$-caryophyllene from cloves, which are the aromatic flower buds of a tree, Syzygium aromaticum, in the family Myrtaceae. For the preparation of $\beta$-caryophyllene, steam distillation of dried flower's buds was performed and then the essential oil was obtained. After fractional distillation and concentration of essential oil, $\beta$-caryophyllene was prepared. H-002119-00-001 is obtained from $\beta$-caryophyllene extract. In this study, we investigate the effects of the non-antibiotic compound H-002119-00-001 on the eradication of $H$. pylori in a mouse model and study its effect on the inflammation of gastric mucosa.

\section{Materials and Methods}

\subsection{Materials}

H-002119-00-001 was obtained from SFC Bio., Cheonan, Korea. Metronidazole (MTN), clarithromycin (CLR), and omeprazole were purchased from Sigma-Aldrich Corp. (St Louis, MI, USA).

\subsection{Ethics}

The Institutional Animal Care and Use Committee at the National Center of Efficacy Evaluation for the Development of Health Products Targeting Digestive Disorders, Incheon, Korea, approved the animal procedures conducted on rats.

\subsection{In Vitro Quantification of Colony Forming Units (CFUs)}

H. pylori KCTC12083 (Korea Collection for Type Culture, Daejeon, Korea) was used for the in vitro experiment. Bacteria were cultured in Columbia agar with $5 \%$ sheep's blood and incubated at $37^{\circ} \mathrm{C}$ under micro-aerobic conditions. To determine the antimicrobial effect of $\beta$-caryophyllene, H. pylori KCTC12083 was inoculated into $\left(10^{5-6} \mathrm{CFU} / \mathrm{mL}\right) 10 \mathrm{~mL}$ phosphate-buffered saline (PBS) and dilutions of 1:10, 1:100, and 1:1000 H-002119-00-001 were prepared. H-002119-00-001 was added to the suspension of $H$. pylori KCTC12083 and vortexed. The mixture was inoculated onto Columbia agar plates containing sheep's blood (5\%). The no-treatment group served as the control group. The number of bacterial colonies was determined after $84 \mathrm{~h}$.

\subsection{Inoculation of Experimental Animals}

Male C57BL/6 mice (4-week-old) were purchased from Central Lab. Animal Inc., Seoul, Korea. H. pylori SS1 strain was used for inoculation. Bacteria were maintained in trypticase soy agar (Difco Laboratories Inc., Detroit, MI, USA) containing sheep's blood (5\%) and incubated at $37^{\circ} \mathrm{C}$ under micro-aerobic conditions $\left(10 \% \mathrm{CO}_{2}, 85 \% \mathrm{~N}_{2}\right.$, and $\left.5 \% \mathrm{O}_{2}\right)$ for 2-3 days. For the assessment of anti- $H$. pylori effect in vivo, 160 mice were acclimatized for 1 week before the experiment. After acclimatization, mice were fasted for $12 \mathrm{~h}$ before H. pylori infection. Towards this, 120 mice were orally administered $200 \mu \mathrm{L}$ of $5.0 \times 10^{9} \mathrm{CFU} / \mathrm{mL}$ H. pylori suspension for three times at 2-day intervals. Non-infected mice, serving as the normal control group, were orally administered an equivalent volume of PBS.

\subsection{Distribution of Animals}

After 2 weeks of $H$. pylori infection, plasma was isolated from the facial vein blood from all mice. Antibodies against $H$. pylori were measured using the mouse H. pylori antibody (IgG) ELISA kit 
(Cusabio Biotech Co., Houston, TX, USA), and only those mice that exhibited elevated H. pylori IgG levels were used for further experiments. After this, the mice were divided into eight groups $(n=10)$ : Group 1 and Group 3 were orally administered with $5 \mathrm{~mL} / \mathrm{kg}$ corn oil every day for 2 weeks; Group 2 and Group 4 were orally administered $5 \mathrm{~mL} / \mathrm{kg}$ of $0.5 \%$ carboxymethyl cellulose sodium salt (CMC) every day for 2 weeks; Group 5 was orally administered with $5 \mathrm{~mL} / \mathrm{kg}$ of $14.2 \mathrm{mg} / \mathrm{kg}$ metronidazole $(\mathrm{MTN})+7.15 \mathrm{mg} / \mathrm{kg}$ clarithromycin (CLR) $+138 \mathrm{mg} / \mathrm{kg}$ omeprazole every day for 2 weeks; Group 6 was orally administered with $5 \mathrm{~mL} / \mathrm{kg}$ of $100 \mathrm{mg} / \mathrm{kg} \mathrm{H}-002119-00-001$; Group 7 was orally administered with $5 \mathrm{~mL} / \mathrm{kg}$ of $200 \mathrm{mg} / \mathrm{kg} \mathrm{H-002119-00-001;} \mathrm{Group} 8$ was orally administered with $5 \mathrm{~mL} / \mathrm{kg}$ of 500 $\mathrm{mg} / \mathrm{kg} \mathrm{H}-002119-00-001$. H-002119-00-001 was administered to the mice once daily for 2 and 4 weeks (Figure 1A,B).

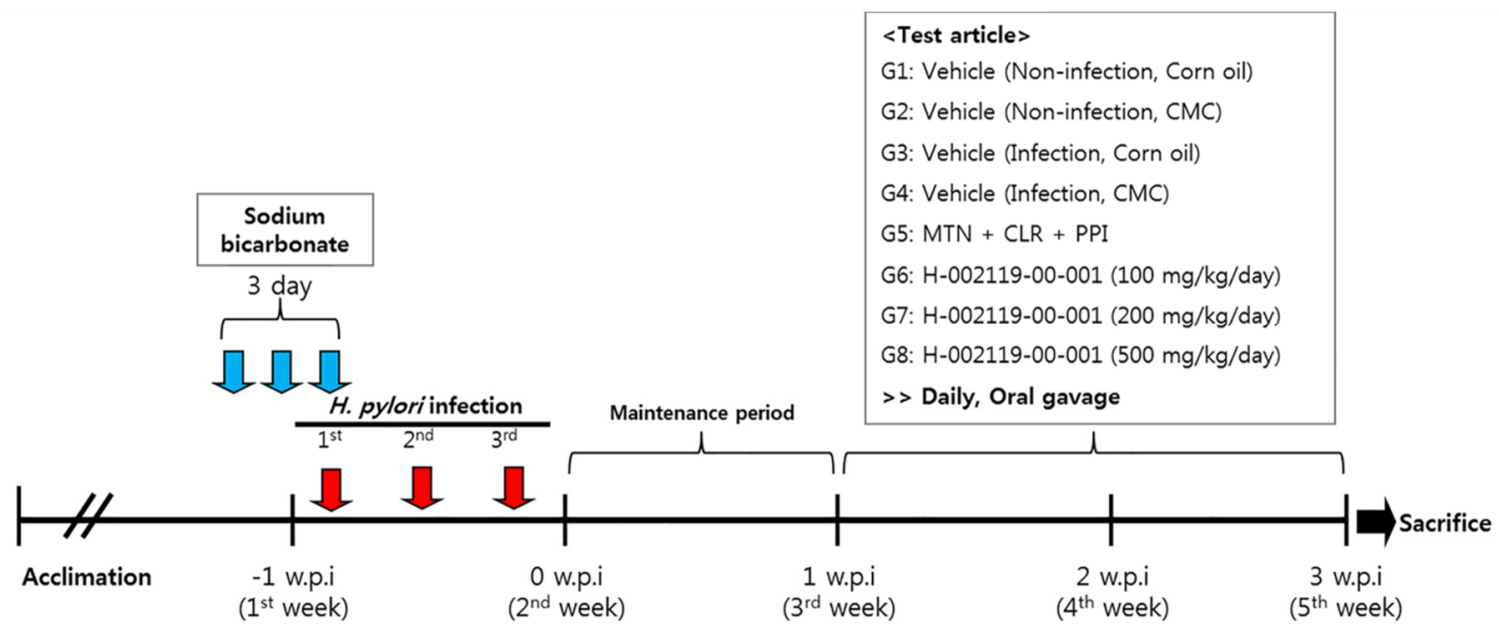

(A)

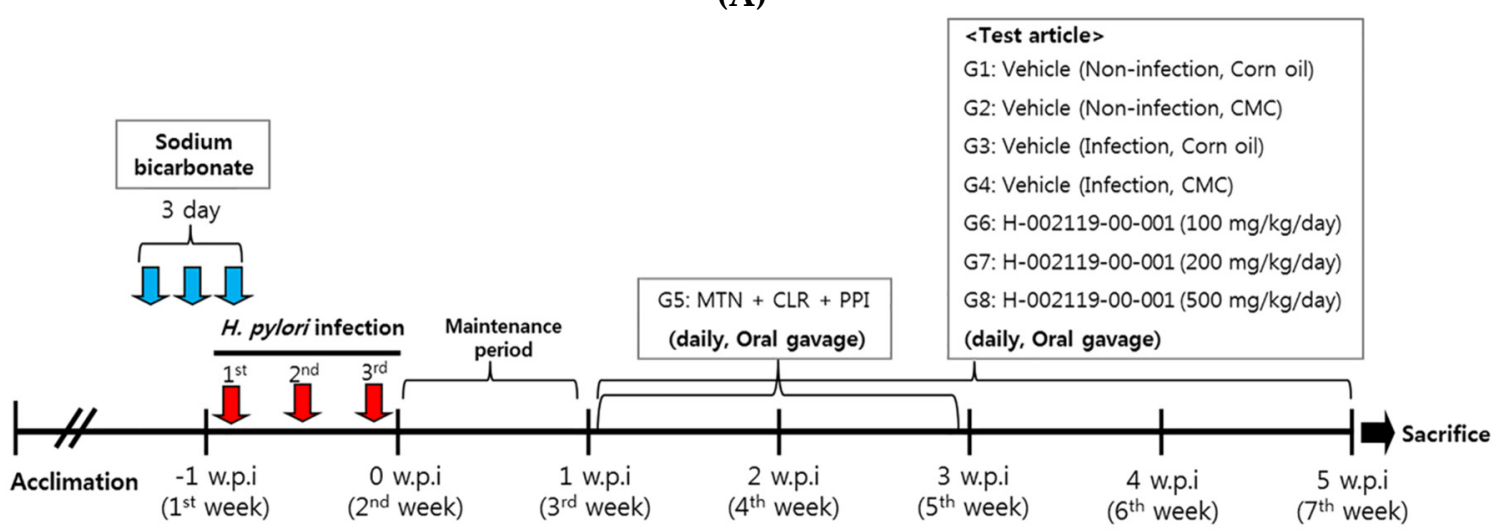

(B)

Figure 1. Design of animal experiments. Efficacy of H-002119-00-001 against H. pylori in vivo. This figure depicts the study protocol, including H. pylori inoculation and development of infection in C57BL/6 mice, followed by the treatments. (A) Two week treatment with H-002119-00-001, (B) Four week treatment with H-002119-00-001

\subsection{Bacterial Identification}

At the end of the experiment, animals were euthanized, and stomachs were removed from their abdominal cavities. The gastric mucosa from the pylorus was biopsied for the Campylobacter-like organisms (CLO) test. 


\subsection{CLO Test}

The gastric mucosal tissue extracted on the day of autopsy was aseptically collected and tested using CLO test reagent (Asan Pharmaceutical Co., Seoul, Korea). After $2 \mathrm{~h}$ of incubation at $37^{\circ} \mathrm{C}$, if the resultant color changed from yellow to red, the result was determined to be positive. After the CLO test, the mean and standard deviation for each group were determined by using the following scale: 0 points for no color change in the medium, 1 point for slightly red color, 2 points for light purple, and 3 points for dark purple.

\subsection{Real-Time Polymerase Chain Reaction (qpcr) for Identifying H. Pylori in Gastric Mucosa}

RNA was collected from gastric mucosal tissue, and DNA was synthesized to perform PCR. qPCR was performed using specific primers. The marker gene used in this experiment was the 16S rRNA specific for $H$. pylori. Primers specific for $H$. pylori $16 \mathrm{~S}$ rRNA were used; these were 5'-CTTAACCATAGAACTGCATTTGAAACTAC-3' (forward) and 5'-GGTCGCCTTCGCAATGAGTA-3' (reverse). The results represent the mean and error between groups through the relative quantitative calculation of the $\Delta \mathrm{Ct}$ (threshold cycle) value.

\subsection{Histopathological Assessment}

\subsubsection{Histological Evaluation}

Stomachs were removed and dissected along the greater curvature in the different mice groups. These were then fixed in $10 \%$ formalin, paraffin-embedded, sectioned to $4 \mu \mathrm{m}$, and stained with hematoxylin \& eosin (H\&E), and histopathological examination was performed. Histopathological scores indicated overall gastritis with damage to the surface epithelium, inflammatory cell infiltration, and submucosal edema, all of which were collectively found in the entire corpus and antrum region of mice. After measuring the degree of atrophic gastritis using the strategy used in previous studies [25,26], the grade of each tissue was recorded in terms of scores. Then, the sum of the detailed scores of each organization was calculated, followed by measuring the average score of each group; the scores were calculated by two different researchers to increase objectivity. The score was classified as 0 points if not observed for each item, 0.5 points for mild, and 1 point for moderate.

\subsubsection{Immunohistochemistry}

After paraffin embedding, tissue slides were subjected to immunostaining through deparaffinization and hydration. Antigen retrieval was performed to help in visualizing the antigen after blocking the endogenous enzyme in the tissue (blocking of endogenous enzyme). After staining with a macrophage-specific F4/80 antibody (Monoclonal Antibody (BM8), \#14-4801-82, Thermo Fisher), the sample was probed with the secondary antibody, followed by DAB treatment. After the nuclei were stained with hematoxylin, samples were dehydrated, mounted, and observed under a microscope. Referring to a previous study [27], mild and moderate can be expressed as follows: moderate (1+) in case of positive reaction in both lamina propria and muscularis mucosa in gastric tissue, none (0) in otherwise, and mild (0.5+) in the meantime. The average score of each group was calculated, and scores were calculated based on observations by two different researchers to increase objectivity.

\subsection{Statistical Analysis}

Data are presented as means \pm standard error $(\mathrm{SE})$, and groups were compared using the non-parametric Mann-Whitney test. A $p$-value $<0.05$ was considered statistically significant. The results were statistically processed using Sigma plots (Sigmaplot 12.2, Systat Software Inc., San Jose, CA, USA). 


\section{Results}

\subsection{In Vitro Effect of H-002119-00-001 on Bacterial Colonization}

The antimicrobial efficacy of H-002119-00-001 against H. pylori KCTC12083 was evaluated at a dose of $0.001,0.01,0.1$, and $1 \mathrm{M}$. In the control group bacteria were present $\left(10.0 \times 10^{5} \mathrm{CFU} / \mathrm{mL}\right)$. After treatment with $1 \mathrm{M} \mathrm{H-002119-00-001,} \mathrm{the} \mathrm{number} \mathrm{of} \mathrm{bacteria} \mathrm{was} \mathrm{estimated} \mathrm{as} 1.1 \times 10^{2} \mathrm{CFU} / \mathrm{mL}$. The H. pylori eradication rate of H-002119-00-001 at a concentration of $1 \mathrm{M}$ was 99.9\% (Figure 2A,B). However, the other doses of H-002119-00-001 did not show the significant antimicrobial efficacy against H. pylori KCTC12083 (Figure S1).

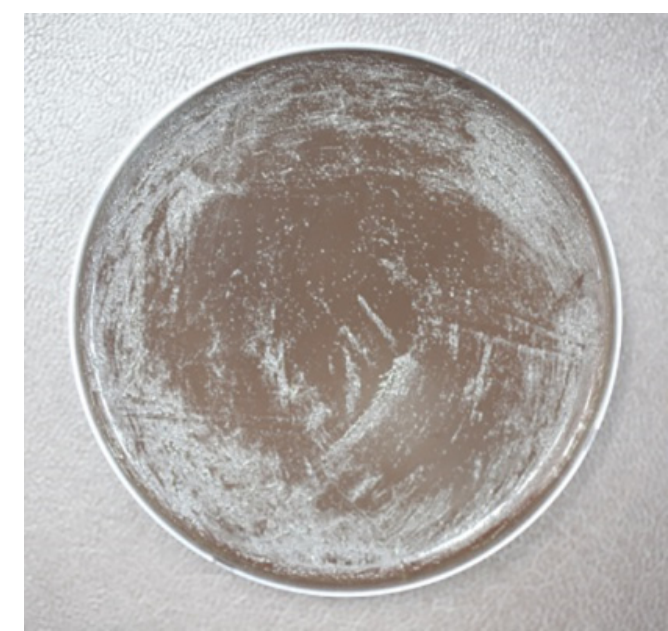

(A)

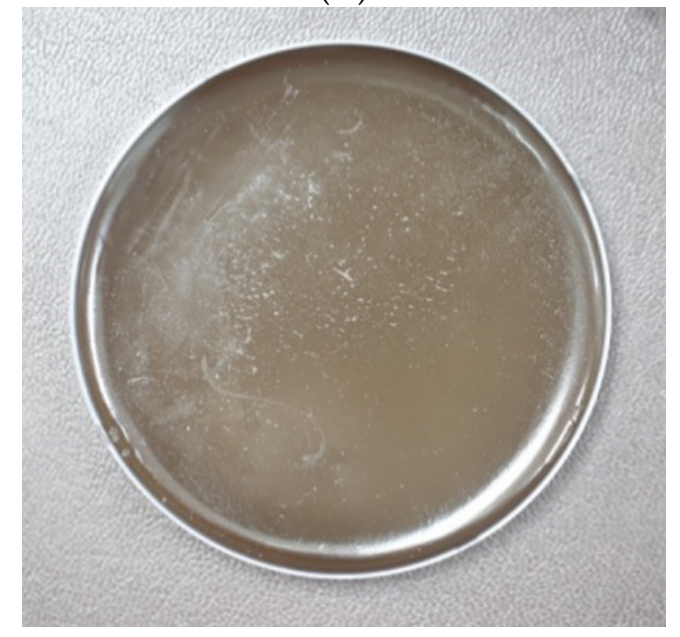

(B)

Figure 2. Anti-H. pylori efficacy of H-002119-00-001 in vitro. (A) The no-treatment group served as the control group. (B) After treatment with $1 \mathrm{M} \mathrm{H}-002119-00-001$, the number of bacteria decreased from $10.0 \times 10^{5}$ to $1.1 \times 10^{2} \mathrm{CFU} / \mathrm{mL}$.

\subsection{CLO Test and qPCR for H. Pylori in the Gastric Mucosa}

The CLO test was performed on the extracted gastric tissue to determine the cure rate. When H-002119-00-001 was administered to the mice once daily for 2 weeks, the treatment rate for Group 6 was $40.0 \%$, for Group 7 it was $60.0 \%$, and for Group 8 it was 70.0\% (Table 1). When H-002119-00-001 was administered to the mice once daily for 4 weeks, the treatment rate for Group 6 was $60.0 \%$, for Group 7 it was $55.6 \%$, and for Group 8 it was $80.0 \%$ (Table 1). H. pylori treatment rate of H-002119-00-001 increased dose-dependently. qPCR for $H$. pylori was conducted to evaluate the therapeutic effect of 
H-002119-00-001 in H. pylori-infected mice. When H-002119-00-001 was administered to the mice once daily for 2 weeks, there was a significant decrease in H. pylori levels in Group 8 (57.1\%) compared to that in Group 3 (Figure 3A). When H-002119-00-001 was administered to the mice once daily for 4 weeks, the $H$. pylori levels in Group 8 showed a statistically significant decrease (58.6\%) compared to that in Group 3 (Figure 3B).

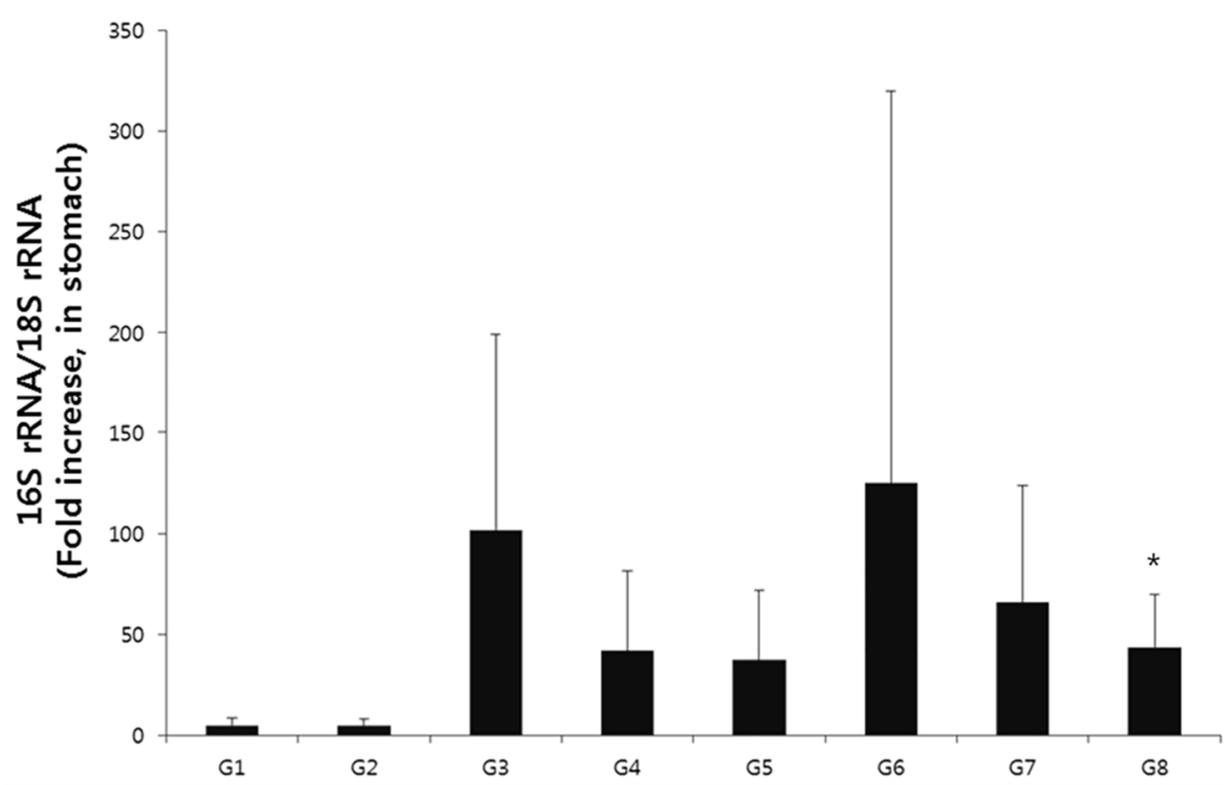

(A)

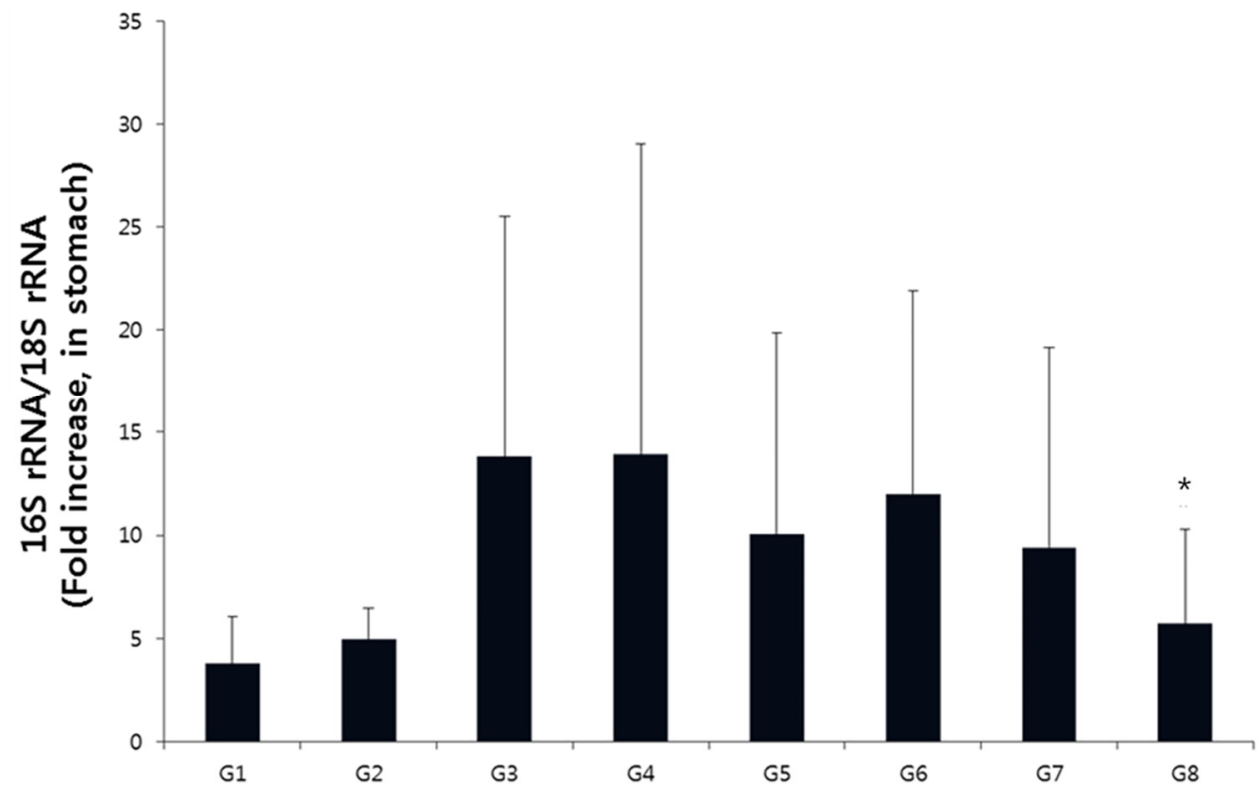

(B)

Figure 3. Effect of H-002119-00-001 on the qPCR score in gastric tissue. (A) Two-week treatment with H-002119-00-001, * Significantly different from Group III $(p<0.05)$. (B) Four-week treatment with H-002119-00-001. * Significantly different from Group III $(p<0.05)$.

\subsection{Gastric Histopathological Analysis}

To determine whether the anti-H. pylori effect of H-002119-00-001 influences gastric mucosal inflammation, pathological changes in the gastric tissue were evaluated and scored. To measure the total pathological score, the damage of the surface epithelium, inflammatory cell infiltration, and submucosal edema were observed and calculated. When H-002119-00-001 was administered to 
the mice once daily for 2 weeks, H-002119-00-001 significantly decreased the inflammation in gastric tissues (Figure 4A, Table 2). When H-002119-00-001 was administered to the mice once daily for 4 weeks, H-002119-00-001 also significantly decreased the inflammation in gastric tissues (Figure 4B, Table 2).
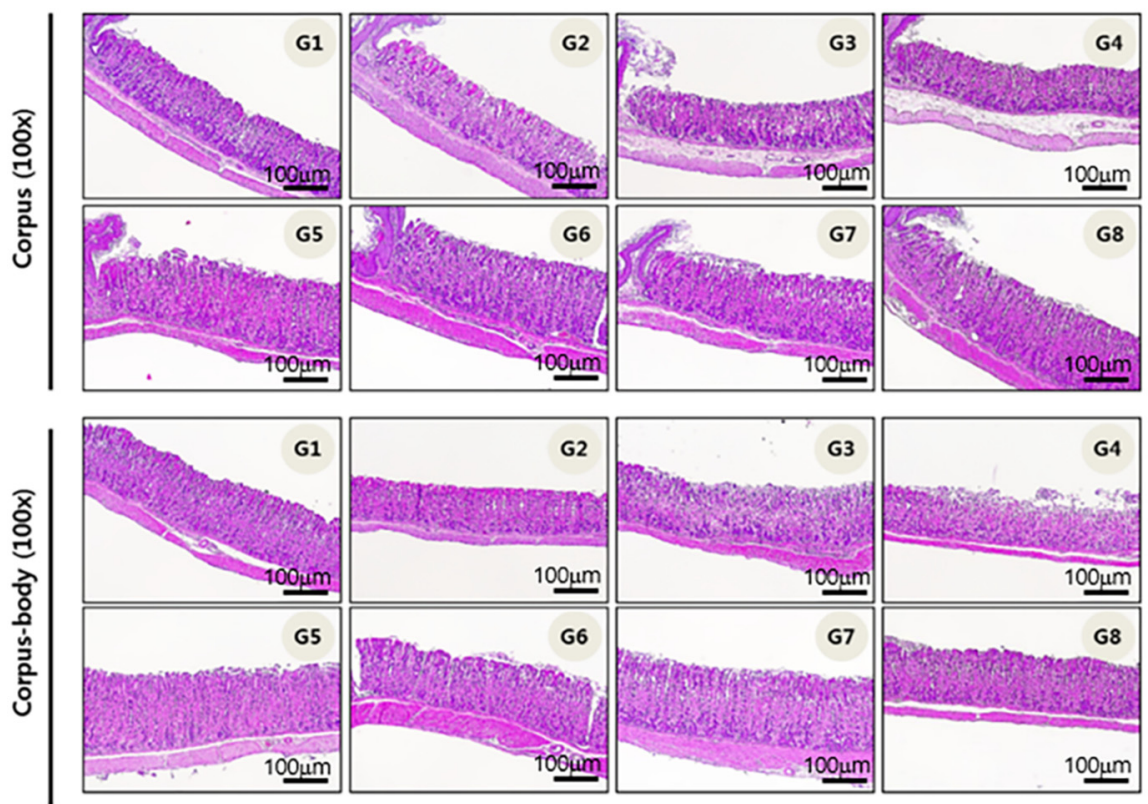

(A)
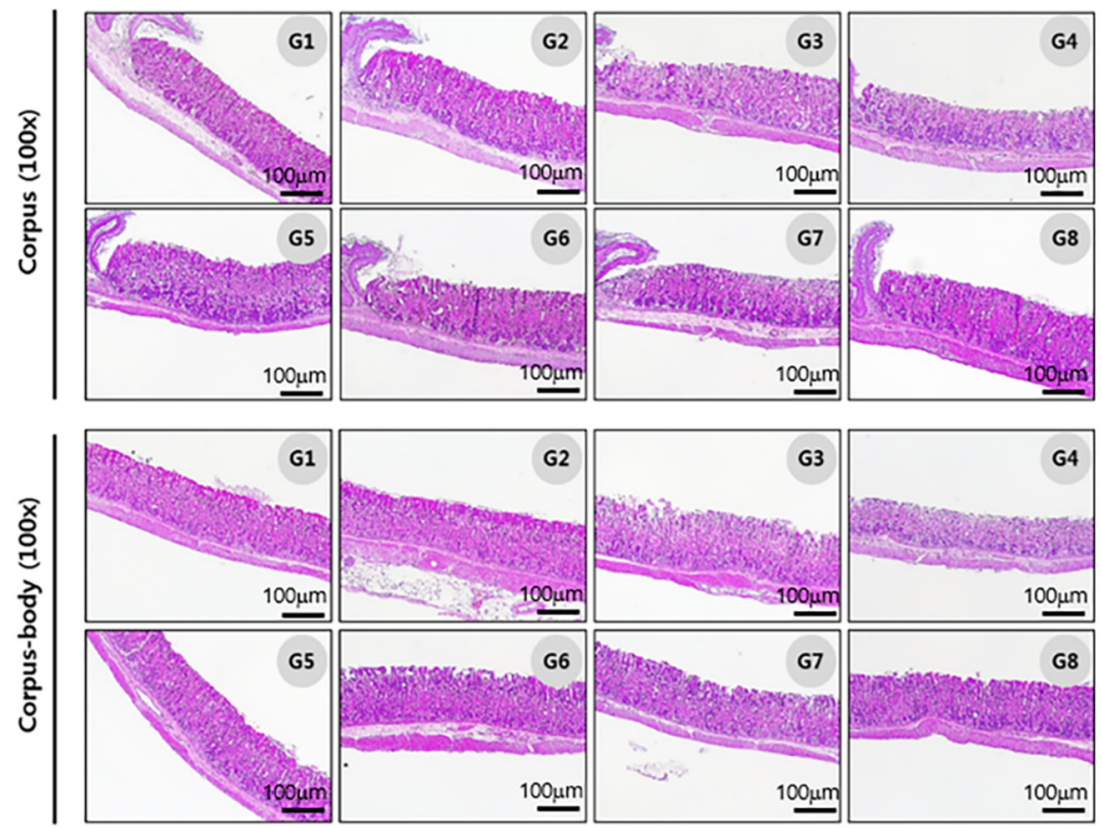

(B)

Figure 4. Effect of H-002119-00-001 on H. pylori infection-induced inflammatory cell infiltration. (A) Two-week treatment with H-002119-00-001, (B) Four-week treatment with H-002119-00-001. 
Table 1. Results of the Campylobacter-like organism (CLO) test with gastric mucosa after treatment.

\begin{tabular}{|c|c|c|c|c|c|c|c|c|}
\hline \multirow[b]{2}{*}{ Group } & \multirow[b]{2}{*}{ H. pylori Infection } & \multirow[b]{2}{*}{ Treatment } & \multicolumn{3}{|c|}{ 2-Week Treatment } & \multicolumn{3}{|c|}{ 4-Week Treatment } \\
\hline & & & $\mathbf{n}$ & $\begin{array}{c}\text { Percentage of } \\
\text { Animals Negative by } \\
\text { CLO Test (\%) }\end{array}$ & CLO Score & $\mathbf{n}$ & $\begin{array}{c}\text { Percentage of } \\
\text { Animals Negative by } \\
\text { CLO Test (\%) }\end{array}$ & CLO Score \\
\hline I & no & corn oil & 10 & 100 & $0.00 \pm 0.00$ & 10 & 100 & $0.00 \pm 0.00$ \\
\hline II & no & $0.5 \% \mathrm{CMC}$ & 9 & 100 & $0.00 \pm 0.00$ & 9 & 100 & $0.00 \pm 0.00$ \\
\hline III & yes & corn oil & 10 & 0 & $3.00 \pm 0.00$ & 10 & 30 & $2.10 \pm 1.45$ \\
\hline IV & yes & $0.5 \% \mathrm{CMC}$ & 9 & 0 & $2.78 \pm 0.44$ & 10 & 40 & $1.70 \pm 1.49$ \\
\hline $\mathrm{V}$ & yes & MTN + CLR + PPI & 10 & 80 & $0.20 \pm 0.42$ & 10 & 70 & $0.90 \pm 1.45$ \\
\hline VI & yes & 100 mg/kg H-002119-00-001 & 10 & 40 & $1.30 \pm 1.25 *$ & 10 & 60 & $1.20 \pm 1.55$ \\
\hline VII & yes & 200 mg/kg H-002119-00-001 & 10 & 60 & $0.50 \pm 0.71 *$ & 9 & 56 & $1.11 \pm 1.45$ \\
\hline VIII & yes & $500 \mathrm{mg} / \mathrm{kg} \mathrm{H}-002119-00-001$ & 10 & 70 & $0.50 \pm 0.85 *$ & 10 & 80 & $0.50 \pm 1.08^{*}$ \\
\hline
\end{tabular}

* Significantly different from Group III $(p<0.05)$.

Table 2. Results of histopathological examination in gastric tissue.

\begin{tabular}{|c|c|c|c|c|c|c|c|c|c|c|}
\hline \multirow[b]{2}{*}{ Group } & \multicolumn{5}{|c|}{ 2-Week Treatment } & \multicolumn{5}{|c|}{ 4-Week Treatment } \\
\hline & $\mathbf{n}$ & $\begin{array}{l}\text { Damage of } \\
\text { the Surface } \\
\text { Epithelium }\end{array}$ & $\begin{array}{l}\text { Inflammatory } \\
\text { Cell Infiltration }\end{array}$ & $\begin{array}{l}\text { Submucosal } \\
\text { Edema }\end{array}$ & Total Score & $\mathbf{n}$ & $\begin{array}{l}\text { Damage of } \\
\text { the Surface } \\
\text { Epithelium }\end{array}$ & $\begin{array}{l}\text { Inflammatory } \\
\text { Cell Infiltration }\end{array}$ & $\begin{array}{c}\text { Submucosal } \\
\text { Edema }\end{array}$ & Total Score \\
\hline I & 10 & $0.25 \pm 0.35$ & $0.25 \pm 0.26$ & $0.10 \pm 0.21$ & $0.60 \pm 0.61$ & 10 & $0.05 \pm 0.16$ & $0.15 \pm 0.24$ & $0.15 \pm 0.24$ & $0.35 \pm 0.47$ \\
\hline II & 9 & $0.28 \pm 0.26$ & $0.28 \pm 0.26$ & $0.11 \pm 0.22$ & $0.67 \pm 0.50$ & 9 & $0.11 \pm 0.22$ & $0.22 \pm 0.26$ & $0.17 \pm 0.25$ & $0.50 \pm 0.43$ \\
\hline III & 10 & $0.65 \pm 0.34$ & $0.50 \pm 0.33$ & $0.55 \pm 0.37$ & $1.70 \pm 0.67$ & 10 & $0.65 \pm 0.24$ & $0.45 \pm 0.37$ & $0.45 \pm 0.28$ & $1.55 \pm 0.55$ \\
\hline IV & 9 & $0.61 \pm 0.33$ & $0.56 \pm 0.30$ & $0.44 \pm 0.46$ & $1.61 \pm 0.74$ & 10 & $0.60 \pm 0.32$ & $0.55 \pm 0.37$ & $0.50 \pm 0.41$ & $1.65 \pm 0.88$ \\
\hline $\mathrm{V}$ & 10 & $0.30 \pm 0.42$ & $0.55 \pm 0.44$ & $0.15 \pm 0.24$ & $1.00 \pm 0.78$ & 10 & $0.35 \pm 0.34$ & $0.40 \pm 0.39$ & $0.35 \pm 0.34$ & $1.10 \pm 0.77$ \\
\hline VI & 10 & $0.30 \pm 0.35$ * & $0.40 \pm 0.32$ & $0.25 \pm 0.35 *$ & $0.95 \pm 0.60 *$ & 10 & $0.40 \pm 0.21 *$ & $0.40 \pm 0.32$ & $0.35 \pm 0.34$ & $1.15 \pm 0.67$ \\
\hline VII & 10 & $0.35 \pm 0.34$ * & $0.25 \pm 0.35$ & $0.25 \pm 0.35 *$ & $0.85 \pm 0.88^{*}$ & 9 & $0.39 \pm 0.42$ & $0.44 \pm 0.39$ & $0.39 \pm 0.33$ & $1.22 \pm 1.00$ \\
\hline VIII & 10 & $0.25 \pm 0.26$ * & $0.25 \pm 0.26$ * & $0.15 \pm 0.34$ * & $0.65 \pm 0.63$ * & 10 & $0.25 \pm 0.26$ * & $0.35 \pm 0.24$ & $0.25 \pm 0.42$ & $0.85 \pm 0.53$ * \\
\hline
\end{tabular}

* Significantly different from Group III $(p<0.05)$. 


\subsection{Gastric Tissue Immunostaining Assay}

We also evaluated macrophages in the gastric tissue to determine the anti- $H$. pylori effects of H-002119-00-001 using immunohistochemistry (IHC). IHC revealed a marked decrease in intramucosal F4/80-positive macrophages in H-002119-00-001-treated gastric tissue, both in the 2-week and 4-week treatments (Figure 5, Table 3).

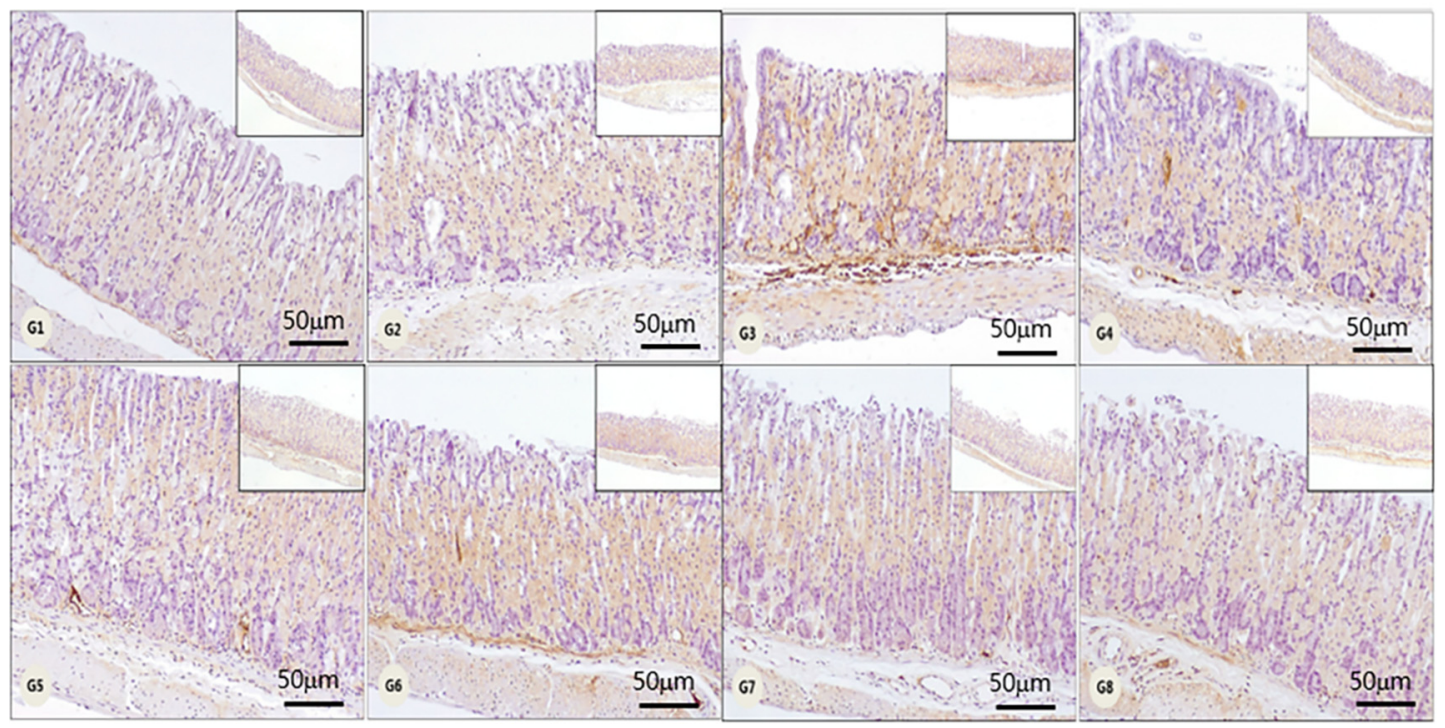

(A)

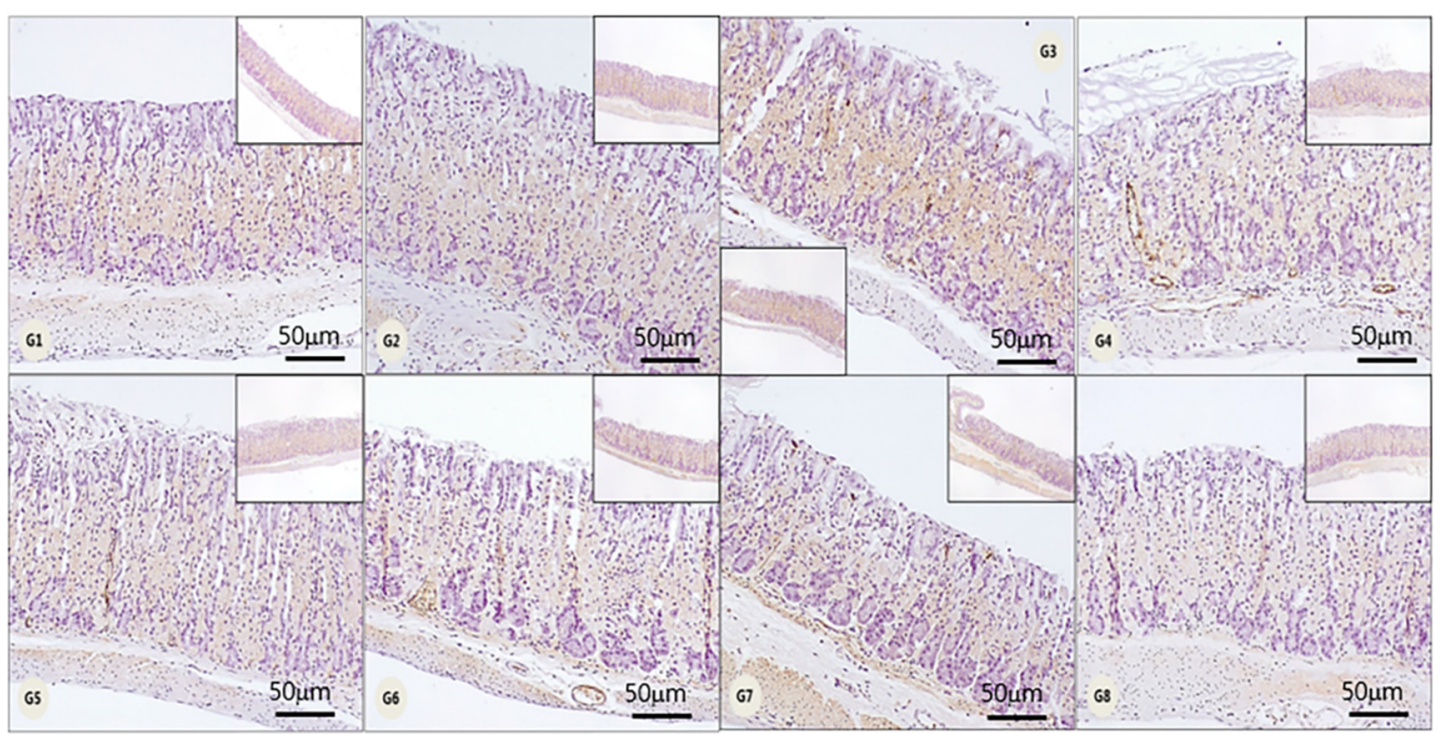

(B)

Figure 5. Effect of H-002119-00-001 on H. pylori infection-induced immune cell infiltration. (A) Two-week treatment with H-002119-00-001, (B) Four-week treatment with H-002119-00-001. 
Table 3. Results of immunohistochemical assessments in gastric tissue.

\begin{tabular}{ccccc}
\hline \multirow{2}{*}{ Group } & \multicolumn{2}{c}{ 2-Week Treatment } & \multicolumn{2}{c}{ 4-Week Treatment } \\
\cline { 2 - 5 } & $\mathbf{n}$ & F4/80 Score & $\mathbf{n}$ & F4/80 Score \\
\hline I & 10 & $0.10 \pm 0.21$ & 10 & $0.10 \pm 0.21$ \\
II & 9 & $0.06 \pm 0.17$ & 9 & $0.15 \pm 0.24$ \\
III & 10 & $0.65 \pm 0.34$ & 10 & $0.58 \pm 0.20$ \\
IV & 9 & $0.44 \pm 0.30$ & 10 & $0.35 \pm 0.34$ \\
V & 10 & $0.55 \pm 0.44$ & 10 & $0.25 \pm 0.35$ \\
VI & 10 & $0.35 \pm 0.24 *$ & 10 & $0.35 \pm 0.41$ \\
VII & 10 & $0.20 \pm 0.26^{*}$ & 9 & $0.22 \pm 0.26$ \\
VIII & 10 & $0.25 \pm 0.26^{*}$ & 10 & $0.20 \pm 0.26 *$ \\
\hline
\end{tabular}

\section{Discussion}

This study was performed to evaluate the antimicrobial efficacy of H-002119-00-001 in a mouse model infected with $H$. pylori compared to that of antibiotic treatment. Moreover, in this study, we focused on identifying new therapeutic agents from natural plants for the eradication of H. pylori-complementary to drugs derived from synthetic sources- that have few side effects and low toxicity. H-002119-00-001 used in this study is a $\beta$-caryophyllene, a natural compound found in essential oils of many plants such as cloves, cannabis sativa, rosemary, and hops [28,29]. Essential oils have been shown to inhibit $H$. pylori in in vitro [30,31] and in vivo studies [32]. However, $\beta$-caryophyllene from essential oils has not been reported for the treatment of $H$. pylori infection. $\beta$-caryophyllene has been known to have anti-inflammatory effects and has showed efficacy with respect to the management of degenerative brain diseases such as depression, cerebral ischemic injury, Alzheimer's disease, and epilepsy [33-37]. In addition, $\beta$-caryophyllene is effective against lymphoma and neuroblastoma because of its anti-inflammatory effects [38]. Therefore, we thought that the anti-inflammatory, antioxidant, and antibacterial activity of $\beta$-caryophyllene might be effective in inhibiting $H$. pylori infection and inflammation in the gastric mucosa. Thus, in this study, we investigated the bactericidal effect of H-002119-00-001 and compared it with the efficacy of antibiotic therapy.

First, we determined the antimicrobial efficacy of H-002119-00-001 using H. pylori KCTC12083 to evaluate the conventional in vitro bactericidal activities. Our result revealed that the H. pylori KCTC 12083 eradication rate of H-002119-00-001 at a concentration of $1 \mathrm{M}$ was $99.9 \%$. Based on this positive result, we conducted a preclinical study to compare these effects with those of the existing antibiotic therapy for eradication of H. pylori. Antibiotic therapy has high efficacy, but it is associated with the development of antibiotic resistance and numerous adverse effects such as drug allergy and gastrointestinal symptoms. The frequent occurrence of adverse effects of antibiotics can lead to reduced compliance of patients. Therefore, because of the increasing rate of antibiotic resistance and adverse effects, it is important to search for new therapeutic agents against $H$. pylori infection. Recently, natural products from plants have received attention for the discovery of new therapeutic agents for the treatment of $H$. pylori. In this preclinical study, no severe adverse effects were observed, and treatment with H-002119-00-001 did not have any significant effect on body weight in mice.

The CLO test and H. pylori PCR in the gastric mucosa after treatment showed that the treatment rate increased as the dose of $\mathrm{H}-002119-00-001$ increased. Group 8 had the highest cure rate $(70 \%$ for 2-week treatment and $80 \%$ for 4 -week treatment) among the treatment groups. Furthermore, the CLO score for Group 8 was the lowest among the treatment groups $(0.50 \pm 0.85$ for 2-week treatment and $0.50 \pm 1.08$ for 4-week treatment). The anti-H. pylori effect of H-002119-00-001 was found to be dose-dependent.

Interestingly, H-002119-00-001-treated mice had significantly reduced levels of $H$. pylori-induced inflammation compared to that in H. pylori-infected but untreated mice. H. pylori-induced chronic 
inflammation contributes to disease pathogenesis [39]. Therefore, a reduction in inflammation, as observed here, is expected to reduce $H$. pylori-induced disease progression.

Our current study has a limitation. The antibiotic treatment used for comparison of the efficacy of H-002119-00-001 against $H$. pylori was composed of metronidazole, clarithromycin, and omeprazole. These antibiotics could be candidates for the first-line treatment of H. pylori. However, the current STT is a combination of clarithromycin, amoxicillin, and PPI, but we did not compare the efficacy of H-002119-00-001 with that of STT, the current worldwide standard for $H$. pylori treatment. In addition, the mechanism underlying the inhibitory effect of H-002119-00-001 with respect to $H$. pylori growth is still unknown. Furthermore, it is unclear whether the anti-inflammatory effect after H-002119-00-001 treatment was caused by the decreased H. pylori number or directly affected H-002119-00-001 to host immune cells. Therefore, further studies about the mechanism underlying the anti-inflammatory effect of the H-002119-00-001 treatment are needed. We evaluated the macrophages in the gastric tissue using immunohistochemistry (IHC). In addition, it is also important to note the neutrophils infiltration in H. pylori-infected gastric mucosa. However, we did not evaluate the neutrophil infiltrations by IHC analysis.

In conclusion, we demonstrated a potent antimicrobial activity of H-002119-00-001 against H. pylori. H-002119-00-001 treatment decreased the bacterial burden in vitro as well as in vivo. In addition to its direct killing effect, H-002119-00-001 inhibited the inflammation of the gastric mucosa. Overall, our data suggest that $\mathrm{H}-002119-00-001$ is a promising candidate as an anti-H. pylori agent.

Supplementary Materials: The following are available online at http:/www.mdpi.com/2072-6643/12/4/1000/ s1, Figure S1. In vitro effect of H-002119-00-001 on bacterial colonization (A) After treatment with $0.1 \mathrm{M}$ H-002119-00-001, the number of bacteria showed over $3.0 \times 10^{2} \mathrm{CFU} / \mathrm{mL}$. (B) After treatment with $0.01 \mathrm{M}$ $\mathrm{H}-002119-00-001$, the number of bacteria showed over $3.0 \times 10^{2} \mathrm{CFU} / \mathrm{mL}$. (C) After treatment with $0.001 \mathrm{M}$ $\mathrm{H}-002119-00-001$, the number of bacteria showed over $3.0 \times 10^{2} \mathrm{CFU} / \mathrm{mL}$.

Author Contributions: Conceptualization, D.H.J., M.H.P., C.J.K., J.Y.L., C.Y.K., I.S.K., C.-H.Y., S.-k.K., W.H.K., and Y.C.L.; Methodology, M.H.P., C.J.K., J.Y.L., C.Y.K., I.S.K., C.-H.Y., and S.-k.K.; Validation, M.H.P., C.J.K., J.Y.L., C.Y.K., I.S.K., C.-H.Y., and S.-k.K.; Formal Analysis, D.H.J. and Y.C.L.; Investigation, D.H.J. and M.H.P.; Resources, M.H.P.; Data Curation, M.H.P.; Writing-Original Draft Preparation, D.H.J., M.H.P., S.-k.K., and Y.C.L.; Writing-Review and Editing, D.H.J., M.H.P., and Y.C.L.; Visualization, M.H.P.; Supervision, Y.C.L.; Project Administration, S.-k.K.; Funding Acquisition, S.-k.K. All authors have read and agreed to the published version of the manuscript.

Funding: This work was supported by the Ministry of Small and Medium-sized Enterprises (SMEs) and Startups (MSS), Korea, under the Regional Enterprise Open-Innovative Voucher Program (R\&D, grant number P0010753), supervised by the Korea Institute for Advancement of Technology (KIAT).

Conflicts of Interest: The authors declare no conflict of interest.

\section{References}

1. Hooi, J.K.Y.; Lai, W.Y.; Ng, W.K.; Suen, M.M.Y.; Underwood, F.E.; Tanyingoh, D.; Malfertheiner, P.; Graham, D.Y.; Wong, V.W.S.; Wu, J.C.Y.; et al. Global Prevalence of Helicobacter pylori Infection: Systematic Review and Meta-Analysis. Gastroenterology 2017, 153, 420-429. [CrossRef] [PubMed]

2. Kusters, J.G.; van Vliet, A.H.M.; Kuipers, E.J. Pathogenesis of Helicobacter pylori infection. Clin. Microbiol. Rev. 2006, 19, 449-490. [CrossRef] [PubMed]

3. Yucel, O. Prevention of Helicobacter pylori infection in childhood. World J. Gastroenterol. 2014, 20, 10348-10354. [CrossRef] [PubMed]

4. Blanchard, T.G.; Czinn, S.J. Helicobacter pylori acquisition and transmission: Where does it all begin? Gastroenterology 2001, 121, 483-485. [CrossRef] [PubMed]

5. Blaser, M.J.; Atherton, J.C. Helicobacter pylori persistence: Biology and disease. J. Clin. Invest. 2004, 113, 321-333. [CrossRef]

6. Testerman, T.L.; Morris, J. Beyond the stomach: An updated view of Helicobacter pylori pathogenesis, diagnosis, and treatment. World J. Gastroenterol. 2014, 20, 12781-12808. [CrossRef]

7. Marcus, E.A.; Sachs, G.; Scott, D.R. Eradication of Helicobacter pylori Infection. Curr. Gastroenterol. Rep. 2016, 18, 33. [CrossRef] 
8. Roesler, B.M.; Costa, S.C.B.; Zeitune, J.M.R. Eradication Treatment of Helicobacter pylori Infection: Its Importance and Possible Relationship in Preventing the Development of Gastric Cancer. ISRN Gastroenterol. 2012, 2012, 935410. [CrossRef]

9. Beales, I.L.P. Efficacy of Helicobacter pylori eradication therapies: A single centre observational study. BMC Gastroenterol. 2001, 1, 7. [CrossRef]

10. Yeo, Y.H.; Shiu, S.-I.; Ho, H.J.; Zou, B.; Lin, J.-T.; Wu, M.-S.; Liou, J.-M.; Wu, C.-Y. First-line Helicobacter pylori eradication therapies in countries with high and low clarithromycin resistance: A systematic review and network meta-analysis. Gut 2018, 67, 20. [CrossRef]

11. De, R.; Kundu, P.; Swarnakar, S.; Ramamurthy, T.; Chowdhury, A.; Nair, G.B.; Mukhopadhyay, A.K. Antimicrobial activity of curcumin against Helicobacter pylori isolates from India and during infections in mice. Antimicrob. Agents Chemother. 2009, 53, 1592-1597. [CrossRef] [PubMed]

12. Vítor, J.M.B.; Vale, F.F. Alternative therapies for Helicobacter pylori: Probiotics and phytomedicine. Pathog. Dis. 2011, 63, 153-164. [CrossRef]

13. Goderska, K.; Agudo Pena, S.; Alarcon, T. Helicobacter pylori treatment: Antibiotics or probiotics. Appl. Microbiol. Biotechnol. 2018, 102, 1-7. [CrossRef] [PubMed]

14. Tombola, F.; Campello, S.; De Luca, L.; Ruggiero, P.; Del Giudice, G.; Papini, E.; Zoratti, M. Plant polyphenols inhibit VacA, a toxin secreted by the gastric pathogen Helicobacter pylori. FEBS Lett. 2003, 543, 184-189. [CrossRef]

15. Wang, Y.-C. Medicinal plant activity on Helicobacter pylori related diseases. World J. Gastroenterol. 2014, 20, 10368-10382. [CrossRef]

16. Ruggiero, P.; Tombola, F.; Rossi, G.; Pancotto, L.; Lauretti, L.; Del Giudice, G.; Zoratti, M. Polyphenols reduce gastritis induced by Helicobacter pylori infection or VacA toxin administration in mice. Antimicrob. Agents Chemother. 2006, 50, 2550-2552. [CrossRef]

17. Opdyke, D.L. Monographs on fragrance raw materials. Food Cosmet. Toxicol. 1973, 11, 1011-1081. [CrossRef]

18. Prashar, A.; Locke, I.C.; Evans, C.S. Cytotoxicity of clove (Syzygium aromaticum) oil and its major components to human skin cells. Cell Prolif. 2006, 39, 241-248. [CrossRef]

19. Demirci, B.; Baser, K.H.; Demirci, F.; Hamann, M.T. New caryophyllene derivatives from Betula litwinowii. J. Nat. Prod. 2000, 63, 902-904. [CrossRef]

20. Agarwal, R.B.; Rangari, V.D. Phytochemical investigation and evaluation of anti-inflammatory and anti-arthritic activities of essential oil of Strobilanthus ixiocephala Benth. Indian J. Exp. Biol. 2003, 41, 890-894.

21. Cho, J.Y.; Chang, H.J.; Lee, S.K.; Kim, H.J.; Hwang, J.K.; Chun, H.S. Amelioration of dextran sulfate sodium-induced colitis in mice by oral administration of beta-caryophyllene, a sesquiterpene. Life Sci. 2007, 80, 932-939. [CrossRef] [PubMed]

22. Singh, G.; Marimuthu, P.; De Heluani, C.S.; Catalan, C.A.N. Antioxidant and biocidal activities of Carum nigrum (seed) essential oil, oleoresin, and their selected components. J. Agric. Food Chem. 2006, 54, 174-181. [CrossRef] [PubMed]

23. Kubo, I.; Chaudhuri, S.K.; Kubo, Y.; Sanchez, Y.; Ogura, T.; Saito, T.; Ishikawa, H.; Haraguchi, H. Cytotoxic and antioxidative sesquiterpenoids from Heterotheca inuloides. Planta Med. 1996, 62, 427-430. [CrossRef]

24. Pichette, A.; Larouche, P.L.; Lebrun, M.; Legault, J. Composition and antibacterial activity of Abies balsamea essential oil. Phytother. Res. 2006, 20, 371-373. [CrossRef] [PubMed]

25. Sipponen, P.; Price, A.B. The Sydney System for classification of gastritis 20 years ago. J. Gastroenterol. Hepatol. 2011, 26, 31-34. [CrossRef] [PubMed]

26. Sidahmed, H.M.A.; Hashim, N.M.; Mohan, S.; Abdelwahab, S.I.; Taha, M.M.E.; Dehghan, F.; Yahayu, M.; Ee, G.C.L.; Loke, M.F.; Vadivelu, J. Evidence of the gastroprotective and anti- Helicobacter pylori activities of $\beta$-mangostin isolated from Cratoxylum arborescens (vahl) blume. Drug Des. Dev. Ther. 2016, 10, 297-313. [CrossRef]

27. Hitkova, I.; Yuan, G.; Anderl, F.; Gerhard, M.; Kirchner, T.; Reu, S.; Röcken, C.; Schäfer, C.; Schmid, R.M.; Vogelmann, R.; et al. Caveolin-1 protects B6129 mice against Helicobacter pylori gastritis. PLoS Pathog. 2013, 9, e1003251. [CrossRef] [PubMed]

28. Ghelardini, C.; Galeotti, N.; Di Cesare Mannelli, L.; Mazzanti, G.; Bartolini, A. Local anaesthetic activity of beta-caryophyllene. Farmaco 2001, 56, 387-389. [CrossRef] 
29. Ormeno, E.; Baldy, V.; Ballini, C.; Fernandez, C. Production and diversity of volatile terpenes from plants on calcareous and siliceous soils: Effect of soil nutrients. J. Chem. Ecol. 2008, 34, 1219-1229. [CrossRef]

30. Imai, H.; Osawa, K.; Yasuda, H.; Hamashima, H.; Arai, T.; Sasatsu, M. Inhibition by the essential oils of peppermint and spearmint of the growth of pathogenic bacteria. Microbios 2001, 106 (Suppl. 1), 31-39.

31. Kalpoutzakis, E.; Aligiannis, N.; Mentis, A.; Mitaku, S.; Charvala, C. Composition of the essential oil of two Nepeta species and in vitro evaluation of their activity against Helicobacter pylori. Planta Med. 2001, 67, 880-883. [CrossRef]

32. Ohno, T.; Kita, M.; Yamaoka, Y.; Imamura, S.; Yamamoto, T.; Mitsufuji, S.; Kodama, T.; Kashima, K.; Imanishi, J. Antimicrobial activity of essential oils against Helicobacter pylori. Helicobacter 2003, 8, 207-215. [CrossRef] [PubMed]

33. Klauke, A.L.; Racz, I.; Pradier, B.; Markert, A.; Zimmer, A.M.; Gertsch, J.; Zimmer, A. The cannabinoid $\mathrm{CB}(2)$ receptor-selective phytocannabinoid beta-caryophyllene exerts analgesic effects in mouse models of inflammatory and neuropathic pain. Eur. Neuropsychopharmacol. 2014, 24, 608-620. [CrossRef] [PubMed]

34. Bahi, A.; Al Mansouri, S.; Al Memari, E.; Al Ameri, M.; Nurulain, S.M.; Ojha, S. beta-Caryophyllene, a CB2 receptor agonist produces multiple behavioral changes relevant to anxiety and depression in mice. Physiol. Behav. 2014, 135, 119-124. [CrossRef] [PubMed]

35. Chang, H.J.; Kim, J.M.; Lee, J.C.; Kim, W.K.; Chun, H.S. Protective effect of beta-caryophyllene, a natural bicyclic sesquiterpene, against cerebral ischemic injury. J. Med. Food 2013, 16, 471-480. [CrossRef] [PubMed]

36. Cheng, Y.; Dong, Z.; Liu, S. beta-Caryophyllene ameliorates the Alzheimer-like phenotype in APP/PS1 Mice through CB2 receptor activation and the PPARgamma pathway. Pharmacology 2014, 94, 1-12. [CrossRef] [PubMed]

37. De Oliveira, C.C.; de Oliveira, C.V.; Grigoletto, J.; Ribeiro, L.R.; Funck, V.R.; Grauncke, A.C.; de Souza, T.L.; Souto, N.S.; Furian, A.F.; Menezes, I.R.; et al. Anticonvulsant activity of beta-caryophyllene against pentylenetetrazol-induced seizures. Epilepsy Behav. 2016, 56, 26-31. [CrossRef]

38. Sain, S.; Naoghare, P.K.; Devi, S.S.; Daiwile, A.; Krishnamurthi, K.; Arrigo, P.; Chakrabarti, T. Beta caryophyllene and caryophyllene oxide, isolated from Aegle marmelos, as the potent anti-inflammatory agents against lymphoma and neuroblastoma cells. Antiinflamm. Antiallergy Agents Med. Chem. 2014, 13, 45-55. [CrossRef]

39. Suarez, G.; Reyes, V.E.; Beswick, E.J. Immune response to H. pylori. World J. Gastroenterol. 2006, 12, 5593-5598. [CrossRef] 